\title{
A Power Conversion Technique with Hierarchical Equalization Charging Topology for $\mathrm{LiFePO}_{4}$ Batteries
}

\author{
Kuo-Ching Tseng ${ }^{1}\left(\mathbb{D}\right.$, Hao-Shiang Huang ${ }^{1}$ and Chun-An Cheng ${ }^{2, *} \mathbb{D}$ \\ 1 Department of Electronic Engineering, National Kaohsiung University of Science and Technology, \\ Kaohsiung City 82445, Taiwan; jerry@nkust.edu.tw (K.-C.T.); u0452811@nkust.edu.tw (H.-S.H.) \\ 2 Department of Electrical Engineering, I-Shou University, Kaohsiung City 84001, Taiwan \\ * Correspondence: cacheng@isu.edu.tw; Tel.: +886-7-6577711 (ext. 6619)
}

check for updates

Citation: Tseng, K.-C.; Huang, H.-S.; Cheng, C.-A. A Power Conversion Technique with Hierarchical Equalization Charging Topology for $\mathrm{LiFePO}_{4}$ Batteries. Micromachines 2021, 12, 1014. https://doi.org/ 10.3390/mi12091014

Academic Editor: Shichun Mu

Received: 3 August 2021

Accepted: 24 August 2021

Published: 26 August 2021

Publisher's Note: MDPI stays neutral with regard to jurisdictional claims in published maps and institutional affiliations.

Copyright: (c) 2021 by the authors. Licensee MDPI, Basel, Switzerland. This article is an open access article distributed under the terms and conditions of the Creative Commons Attribution (CC BY) license (https:// creativecommons.org/licenses/by/ $4.0 /)$.

\begin{abstract}
An energy-storage scheme with hierarchical equalization charging topology applied in a series-connected battery system is proposed in this paper. The proposed hierarchical equalization charging topology (HECT), which combines an equalizer-within module (EWM) and an equalizer between the modules (EBM), is able to rapidly achieve charging balance among a large number of cells in battery modules. The EWM is composed of a buck-boost converter, while a flyback converter constitutes the EBM. Besides, the voltage of each cell in battery modules can be accurately monitored by utilizing the proposed HECT control architecture. In addition, fewer circuit elements are required in the proposed battery equalization system and a faster balancing speed can be achieved. Satisfactory experimental results were obtained by using $12 \mathrm{LiFePO}_{4}$ batteries, and the performance was improved by about $50 \%$ in reducing the battery voltage deviation realized in the proposed battery balancing system, which verified the function of the proposed HECT scheme.
\end{abstract}

Keywords: battery; converter; equalizer

\section{Introduction}

Energy conservation and reduction of carbon dioxide to avoid the greenhouse effect are the goals of clean and green energy promoted by countries all over the world today. Batteries are an important part of clean and green energy technology and are consistent with this goal. The architecture of a renewable energy system is shown in Figure 1. The battery pack not only supplies power to the DC load through the DC bus, but also supplies power to the AC load through the inverter. Due to the high conversion efficiency of batteries, which is far better than the internal combustion engine of gasoline vehicles (GV) [1], the electric vehicle $(\mathrm{EV})$ industry has developed rapidly and has become a hot topic in recent years. On the other hand, portable and wearable storage products are popular development trends for electronic products. Therefore, batteries are also necessary and indispensable components in mobile devices and wearable devices, and their importance is self-evident. The voltage level of the battery is not sufficient to power portable and wearable storage products; for example, the voltage inside a single cell of a Li-ion battery, a lead-acid battery, and a Ni-MH battery is $3.3 \mathrm{~V} \sim 3.7 \mathrm{~V}, 2.4 \mathrm{~V} \sim 2.8 \mathrm{~V}$, and $1.2 \mathrm{~V}$, respectively [2-6]. This means that batteries need to be connected in series to effectively power portable and wearable storage products. For instance, there are 7104 Li-ion cells in a Tesla Model S EV, and these supply $400 \mathrm{~V}$ to the motor [7].

Each individual battery has slightly different characteristics, in terms of manufacturing tolerances or usage conditions, such as inherent resistance, capacity, and life cycle. The unbalance of the series-connected battery will be very serious after many times of charging and discharging [8]. When the battery is in undercharged or overcharged condition, it can cause battery breakdown or even a thermal runaway. Therefore, when the battery is charging or discharging, a battery balancing system is needed to average all of the voltages of the battery in series connection to ensure its safety [9]. To ensure safety and optimize 
performance, all batteries need to be monitored by an electronic battery management system (BMS) [10,11]. Many equalizing methods for batteries have been proposed [12-14]. In terms of hardware, battery equalizers can be classified as dissipative (passive) and non-dissipative (active) types.

The dissipation equalizer [15-17] consumes the charge of the overcharged battery through a resistor until the battery voltage reaches equilibrium. To reduce power losses, the shunt resistors can be replaced by Zener diodes or connected with active switches. Dissipative equalizers are suitable in terms of low capacitance and low power rating, but are not suitable for large battery packs.

Dealing with the voltage difference of the battery cells through the dissipative battery equalizer will result in significant power loss on the resistor. Saving energy and reducing unnecessary energy consumption is an increasingly important issue. Therefore, the nondissipative battery equalizer is regarded as the main research topic in recent years [18-31].

In response to the above requirements, this paper proposes an energy storage scheme with a hierarchical equalization charging topology, which is applied to a series-connected battery system. In addition, in the proposed method, charge balance among a large number of batteries can be quickly achieved, and a faster balance speed can be achieved.

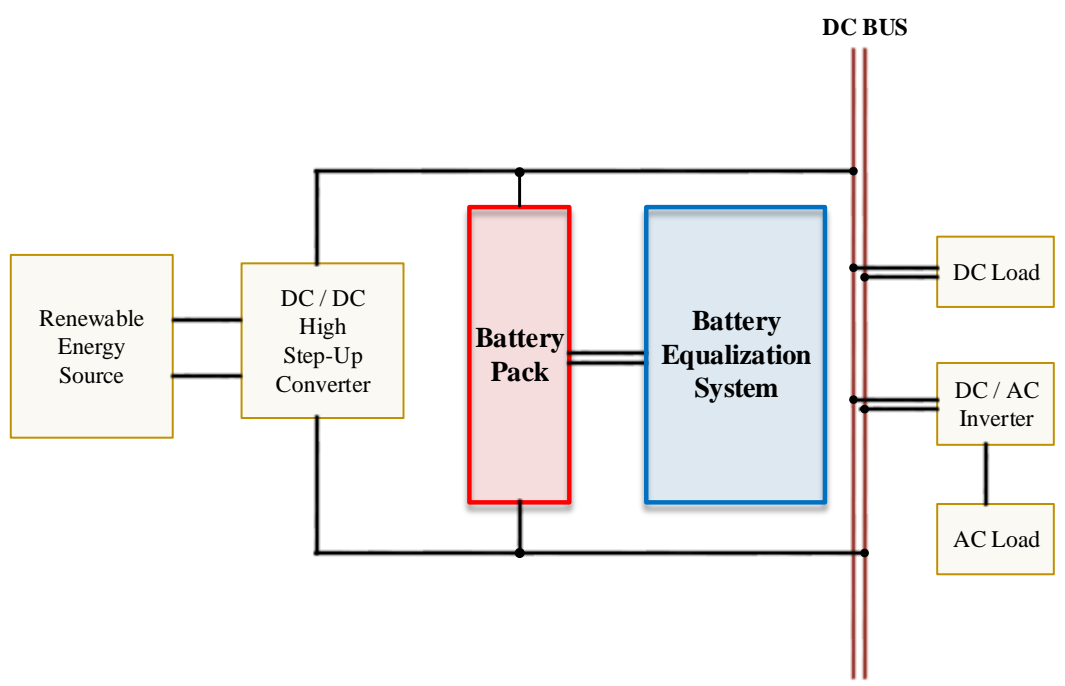

Figure 1. The architecture of a renewable energy system.

\section{The Proposed Hierarchical Equalization Charging Topology}

The proposed battery equalizer system with hierarchical equalization charging topology (HECT) is shown in Figure 2. This system is comprised of the equalizer-within module (EWM), the equalizer between the modules (EBM), and the master control unit (MCU). The main components of the proposed battery equalizer system are introduced as follows.

1. Equalizer-Within Module (EWM)

The cell-by-cell topology is applied in the equalizer-within module. Each battery module is composed of three cells. The main architecture of this equalizer consists of the concentration stage and redistribution stage. Thus, it has great performance and works efficiently with a simple control process.

2. Equalizer between the Modules (EBM)

Each battery pack, where three cells in it have already been equalized, is considered as a single module. Since energy can be transferred between two modules via a longdistance charging or discharging path, the module-to-module topology is the best choice for this equalizer system. The flyback converter with an LC snubber is used to extract energy from the high-voltage module and send it to the low-voltage module. Module selection is operated by relays on four transmission buses (including blue, green, orange, and brown buses). 


\section{Master Control Unit (MCU)}

The master control unit is responsible for voltage sensing, data processing, and driving the equalizers. The MCU of the proposed equalizer system includes LTC-6802-2, arduino UNO, arduino MEGA, and FPGA.

The advantages of the proposed battery equalizer system with hierarchical equalization charging topology are listed as follows.

(1) The most advantageous feature of the cell-by-cell topology is its modularity. In addition, the proposed system applies this topology to each module of three cells. Therefore, it is easy to manufacture when used in a large number of battery packs. In addition, the energy exchange between only three cells in a single module has the advantage of reducing the loss caused by the transmission path.

(2) Since each group of three battery cells is considered as a single module, the number of floating switches required between the modules of the isolated power converter structure can be greatly reduced.

(3) Whether it is an equalizer within a module or an equalizer between modules, the converter used in the equalization system can greatly accelerate the equalization speed.

\section{Equalization within Module (Cell to Cell)}

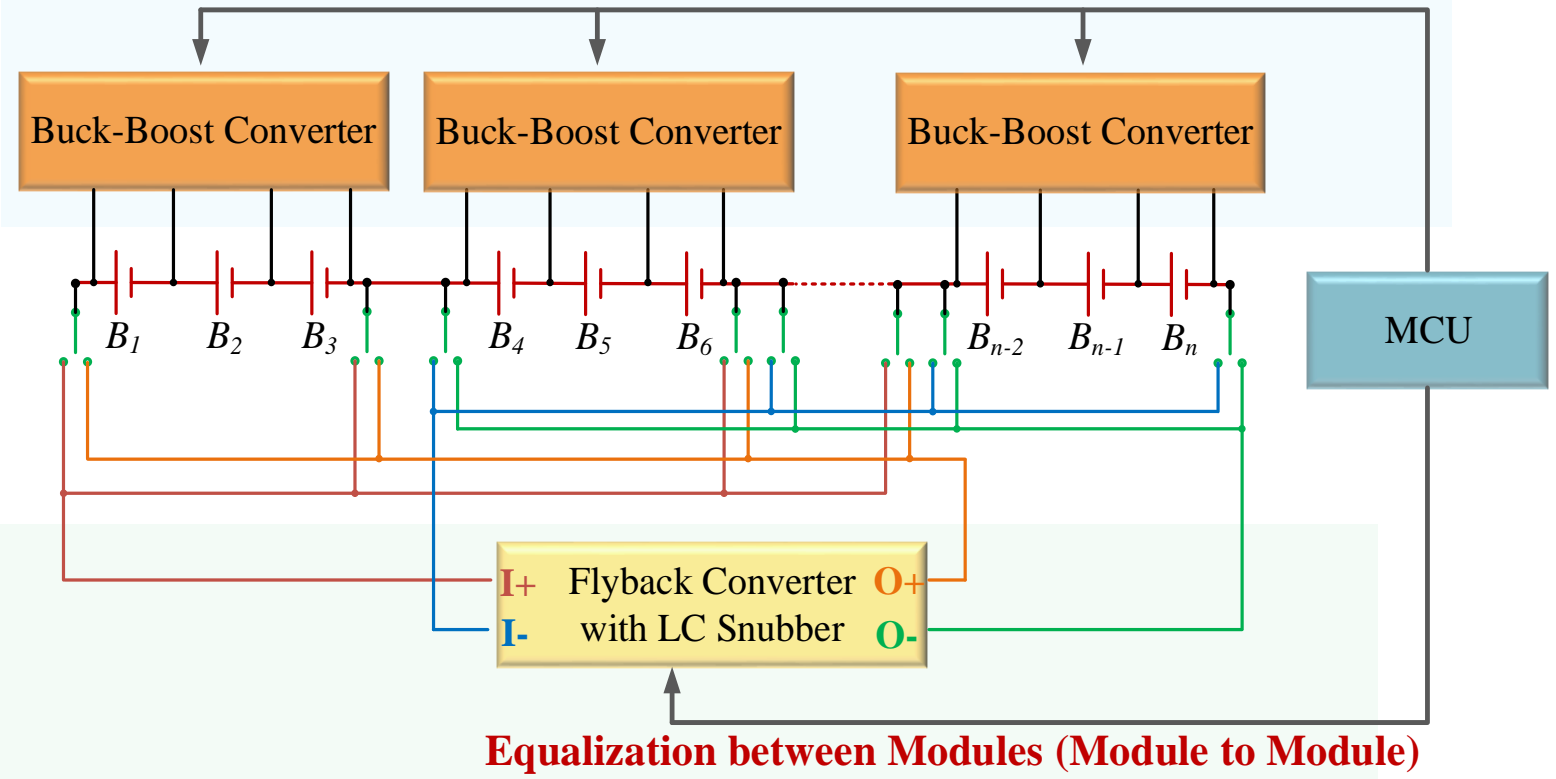

Figure 2. The proposed battery equalizer system with hierarchical equalization charging topology.

\subsection{Equalizer-Within Module (EWM)}

The proposed EWM is shown in Figure 3. This equalizer is a unidirectional buckboost converter, which is composed of a concentration stage and a redistribution stage; the operation principles for each stage are described in the next section. The definition of the component polarity of the equalizer is shown in Figure 4. The energy is collected and redistributed by the battery at the bottom of the module. In addition, in order to achieve high-speed equalization, the main control unit (MCU) will determine the on/off state, and will adjust the duty cycle of the respective gate-driving signals of all power switches according to the battery voltage. 


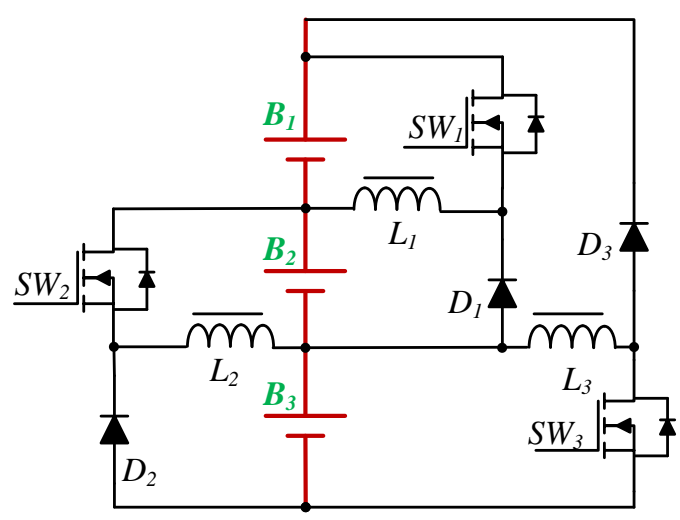

Figure 3. The proposed EWM.

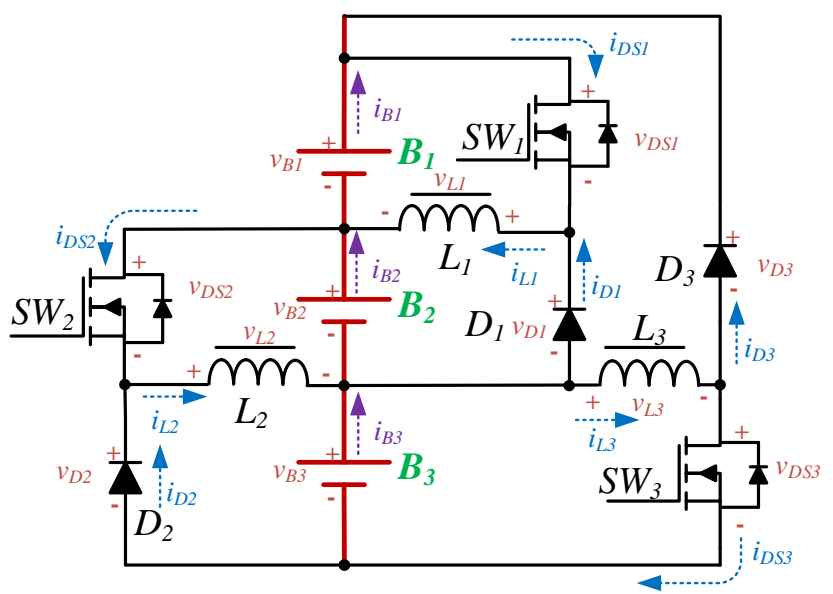

Figure 4. The definition of the component polarity in the EWM.

\subsubsection{Operation Principle of the EWM}

The current path of the concentration stage in Mode 1 is shown in Figure 5. In Figure 5a, switch $S W_{1}$ is turned on, and inductor $L_{1}$ is charged by the battery $B_{1}$. In Figure $5 \mathrm{~b}$, switch $S W_{1}$ is turned off, and the inductor $L_{1}$ provides energy to the battery $B_{2}$. Thus, the energy is unidirectional shifted from $B_{1}$ to $B_{2}$.

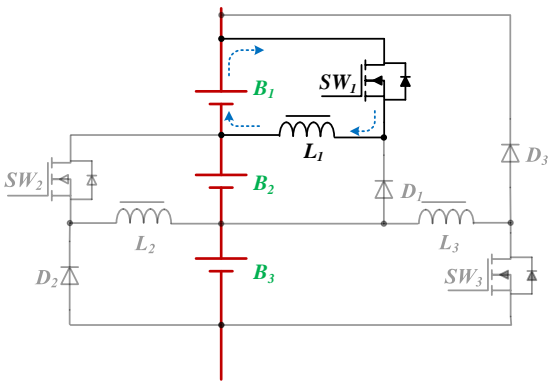

(a)

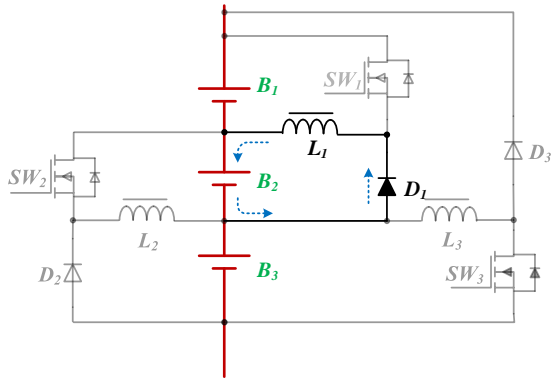

(b)

Figure 5. The current path of the concentration stage in Mode 1: (a) The switch $S W_{1}$ is turned on (b) The switch $S W_{1}$ is turned off.

The current path of the concentration stage in Mode 2 is shown in Figure 6. Similar to Mode 1 , in Mode 2, the energy transferring between batteries $B_{2}$ and $B_{3}$ is shown in Figure $6 a, b$, respectively. 


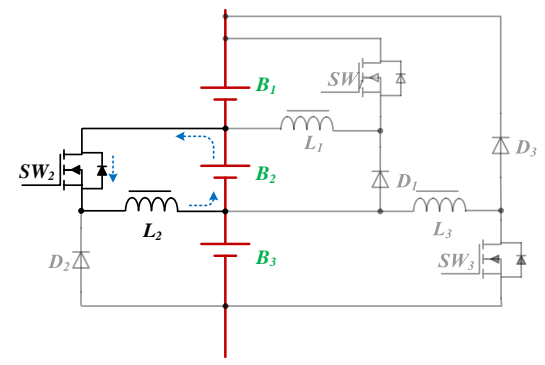

(a)

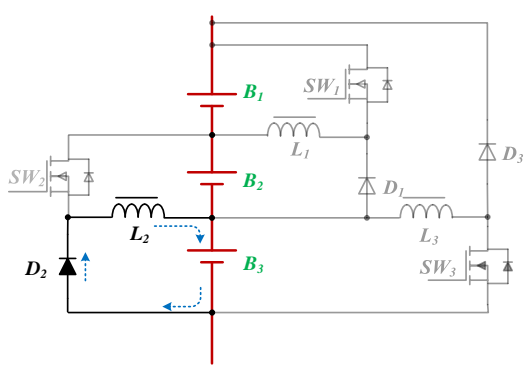

(b)

Figure 6. The current path of the concentration stage in Mode 2: (a) The switch $S W_{2}$ is turned on (b) The switch $S W_{2}$ is turned off.

The current path of the redistribution stage in Mode 3 is shown in Figure 7. In Figure 7a, the power switch $S W_{3}$ is turned on, and the battery $B_{3}$ provides energy to the inductor $L_{3}$ through $S W_{3}$. In Figure $7 \mathrm{~b}$, the switch $S W_{3}$ is turned off, and the inductor $L_{3}$ supplies energy to batteries $B_{1}$ and $B_{2}$.

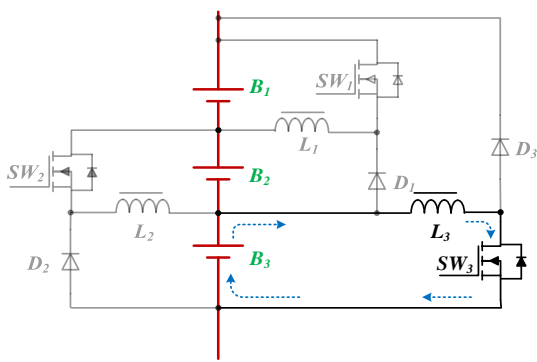

(a)

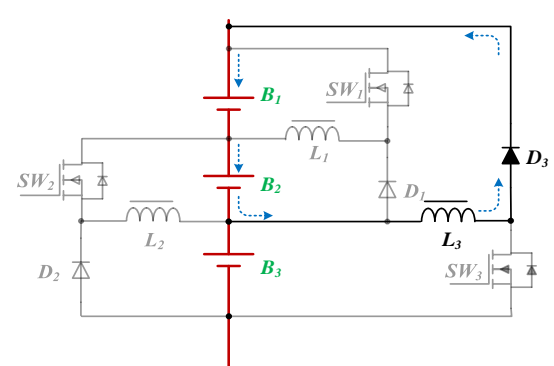

(b)

Figure 7. The current path of the redistribution stage in Mode 3: (a) The switch $S W_{3}$ is turned on (b) The switch $S W_{3}$ is turned off.

\subsubsection{Design of the Energy Storage Elements (Inductors) in the EWM}

In the proposed EWM, digital control is adopted, and the duty cycle of the power switch is adjusted to achieve the balance of the battery. In addition, the inductor inside the equalizer is designed to operate in discontinuous conduction mode (DCM) to control the battery to achieve equilibrium. The inductance $L_{n}$ in the EWM operated at boundaryconduction-mode (BCM) can be derived as [32]:

$$
L_{n} \leq \frac{\left(V_{B n} \cdot D\right)^{2}}{2 \cdot f \cdot P_{o}}
$$

where $V_{B n}$ is the voltage of the battery; $D$ is the duty ratio of the power switch; $f$ is the switching frequency; $P_{O}$ is the output power.

\subsection{Equalizer between Modules (EBM)}

The proposed equalizer between the modules (EBM) is depicted in Figure 8. The EBM uses a traditional flyback converter because it is suitable for low and medium power ratings. In order to reduce losses and improve conversion efficiency, the energy in the leakage inductance can be recycled by a non-dissipative snubber on the primary side of the transformer. Referring to [33], for clamping the voltage to alleviate the voltage stress of the main switch $S W$, the value of the snubber capacitor $C_{s n u}$ is given by:

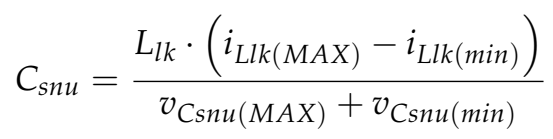




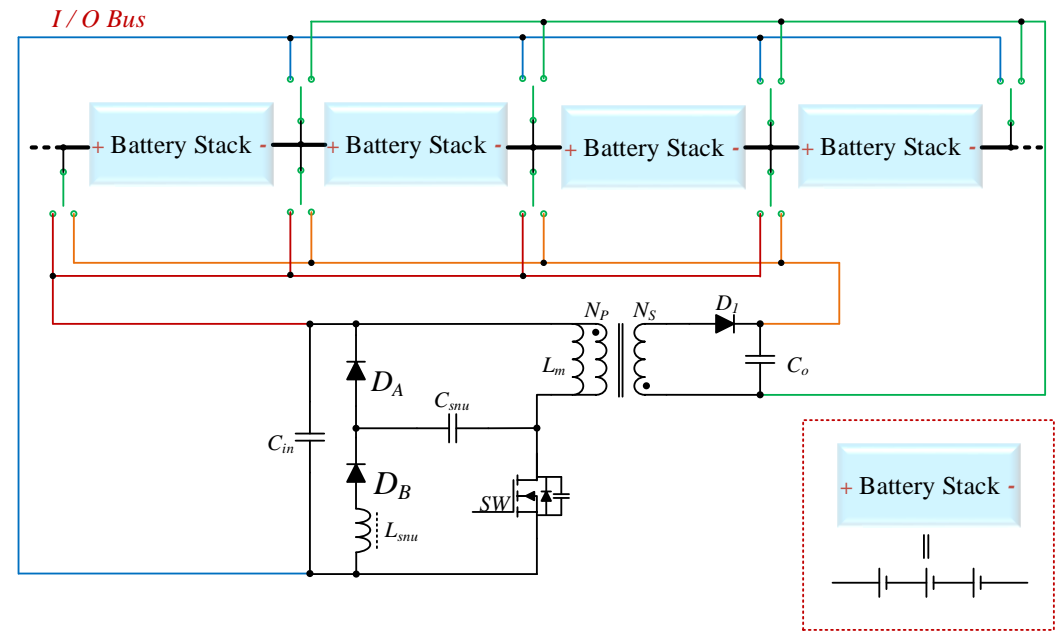

Figure 8. The proposed equalizer between modules.

In this equation, the $i_{L l k(M A X)}$ is the maximum current of leakage inductor during the switch-on period. Moreover, the $i_{L l k(\min )}$ is the maximum current of leakage inductor during the switch-on period. The $v_{C s n u(M A X)}$ is the maximum snubber capacitor voltage. On the contrary, the $v_{\mathrm{Csnu}}(\mathrm{min})$ is the minimum snubber capacitor voltage.

In addition, the snubber is capable to recycle the energy stored in the leakage inductor $L_{l k}$ of the transformer. The snubber inductor $L_{s n u}$ can be expressed as [33]:

$$
L_{s n u}=\frac{D_{\min ^{2}}{ }^{2}}{C_{s n u} \cdot(\pi \cdot f)^{2}}
$$

In this equation, the $D_{\min }$ is the minimum duty cycle of operating equalizer. The $f$ is the operating frequency.

\subsection{Control Architecture of the Proposed Equalizer System}

A previous reference has proved that the control program is the most important factor affecting the speed of battery balancing [33]. In addition, the control program can adjust the battery balance state according to various conditions of the battery pack.

The control architecture of the proposed equalizer system is shown in Figure 9. The controller includes the battery monitor LTC-6802-2, center micro controller unit Arduino UNO and multiplexed controller Arduino MEGA and FPGA. In addition, the battery monitor is responsible for showing the real-time status of cell equalization.

For a large number of cells, the controller system is divided into three parts. The battery voltage data is collected by the battery monitor LTC-6802-2, and then transmitted to the central controller Arduino UNO through the SPI interface. The circuit diagram of LTC6802-2 connected with the Arduino UNO is shown in Figure 10. In addition, the battery data will be displayed on the monitor at the same time, and then sent from Arduino UNO to the Arduino MEGA through the UART interface. Arduino MEGA arranges and specifies the battery to be balanced, and then Arduino MEGA and FPGA send gate-driving signals to each power switch for controlling the equalizer within module. Meanwhile, the Arduino MEGA sends commands to the Relays (LMR1-24D) for controlling the equalizer between module. In addition, the photo of the utilized relays (LMR1-24D) along with the relay drivers in the proposed battery equalization system is shown in Figure 11. The flow charts of the control program for EWM and EBM are shown in Figures 12 and 13, respectively. 


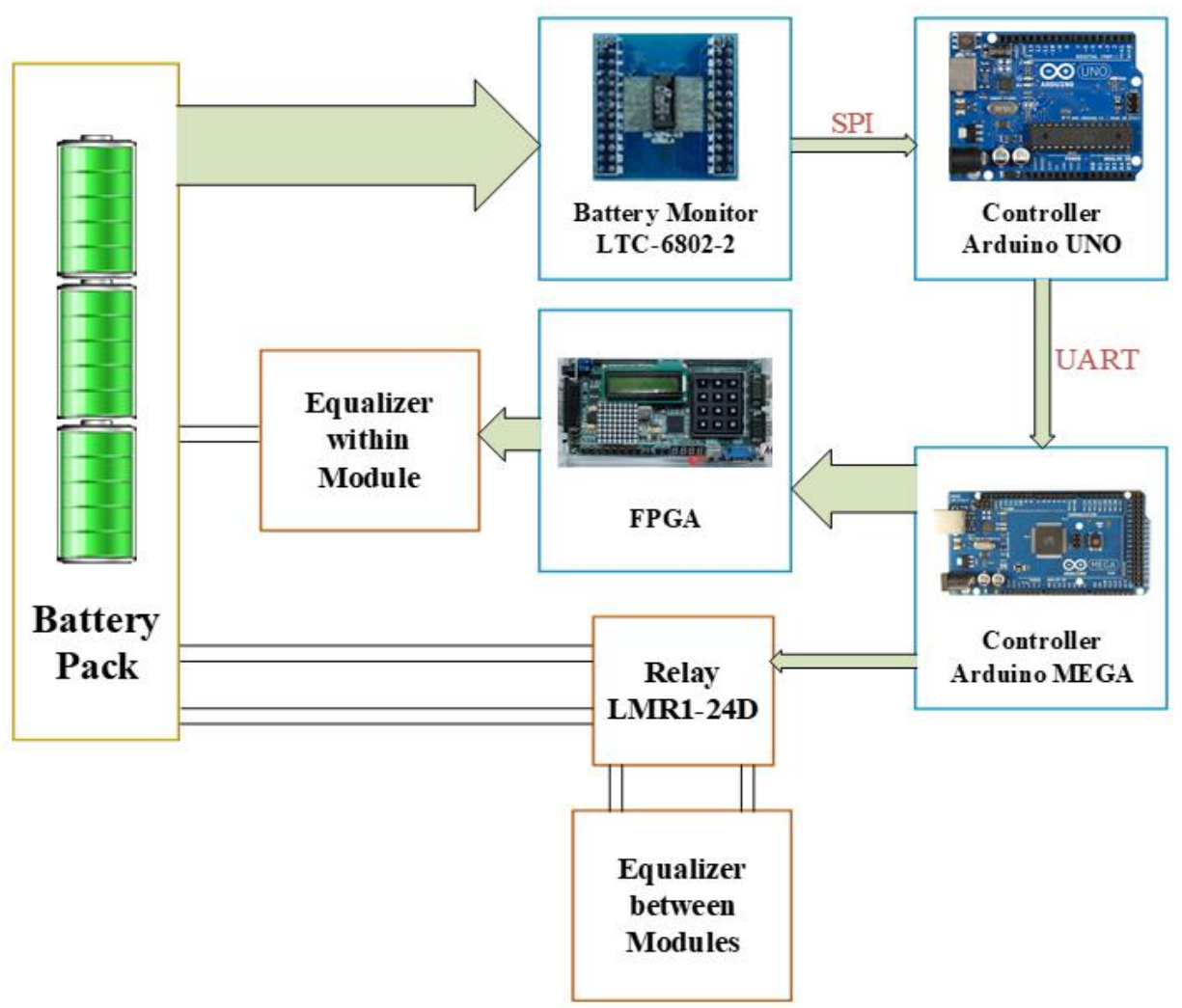

Figure 9. The control architecture of the proposed equalizer system.

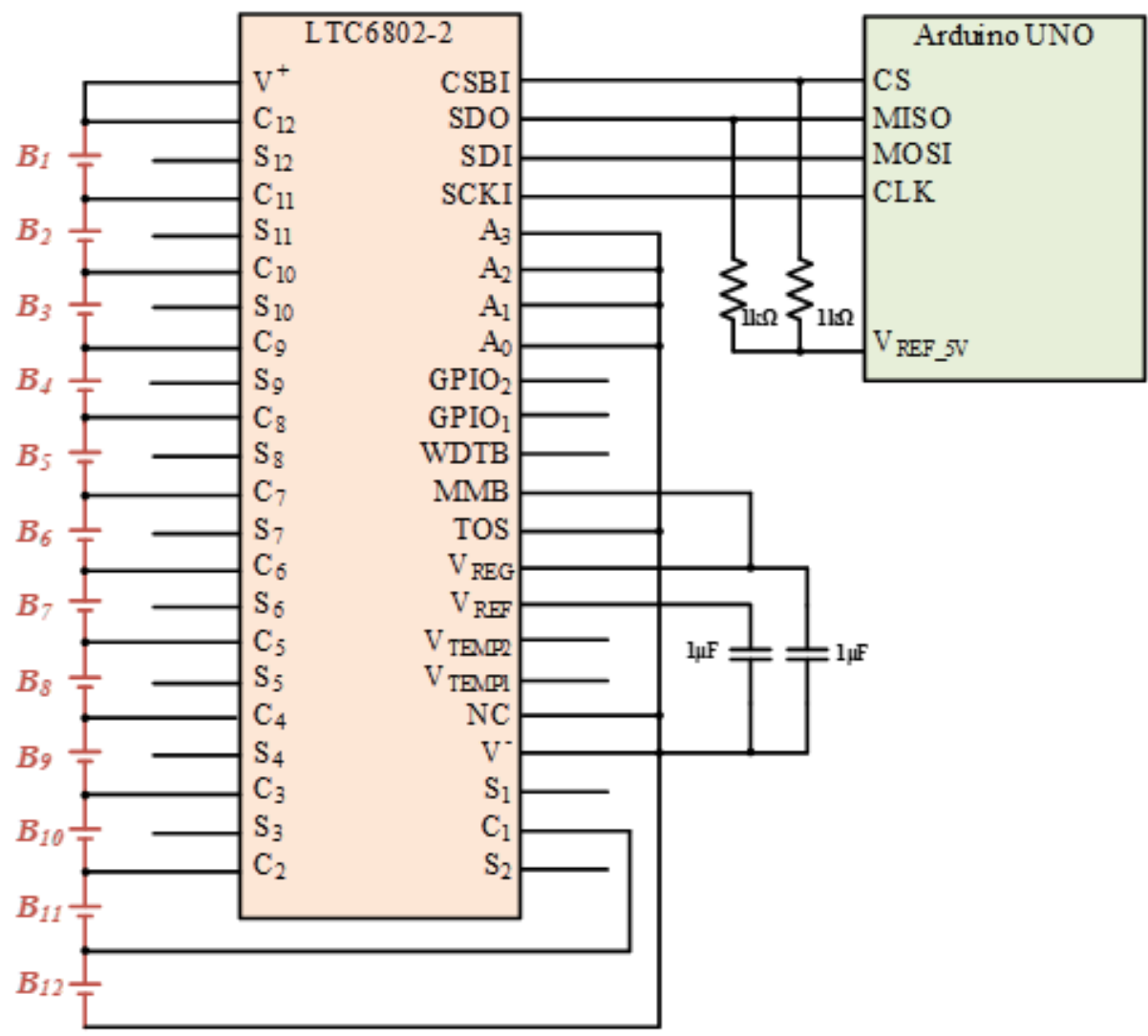

Figure 10. The circuit diagram of LTC-6802-2 connected with the Arduino UNO. 


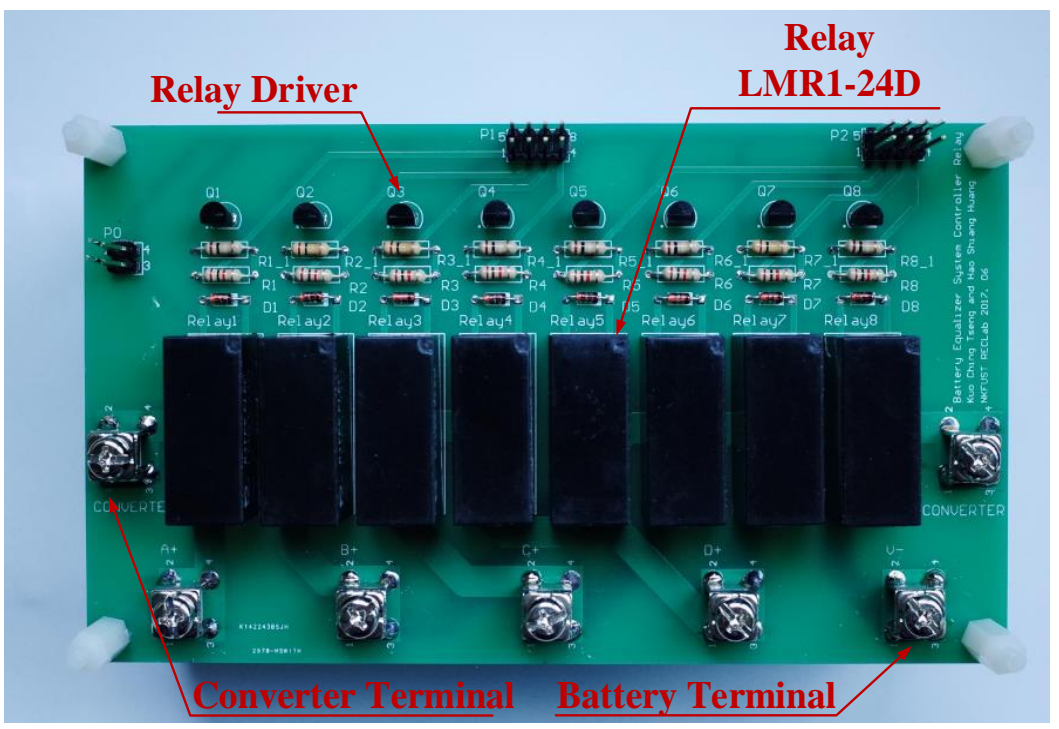

Figure 11. The photo of the utilized relay LMR1-24D in the proposed battery equalization system.

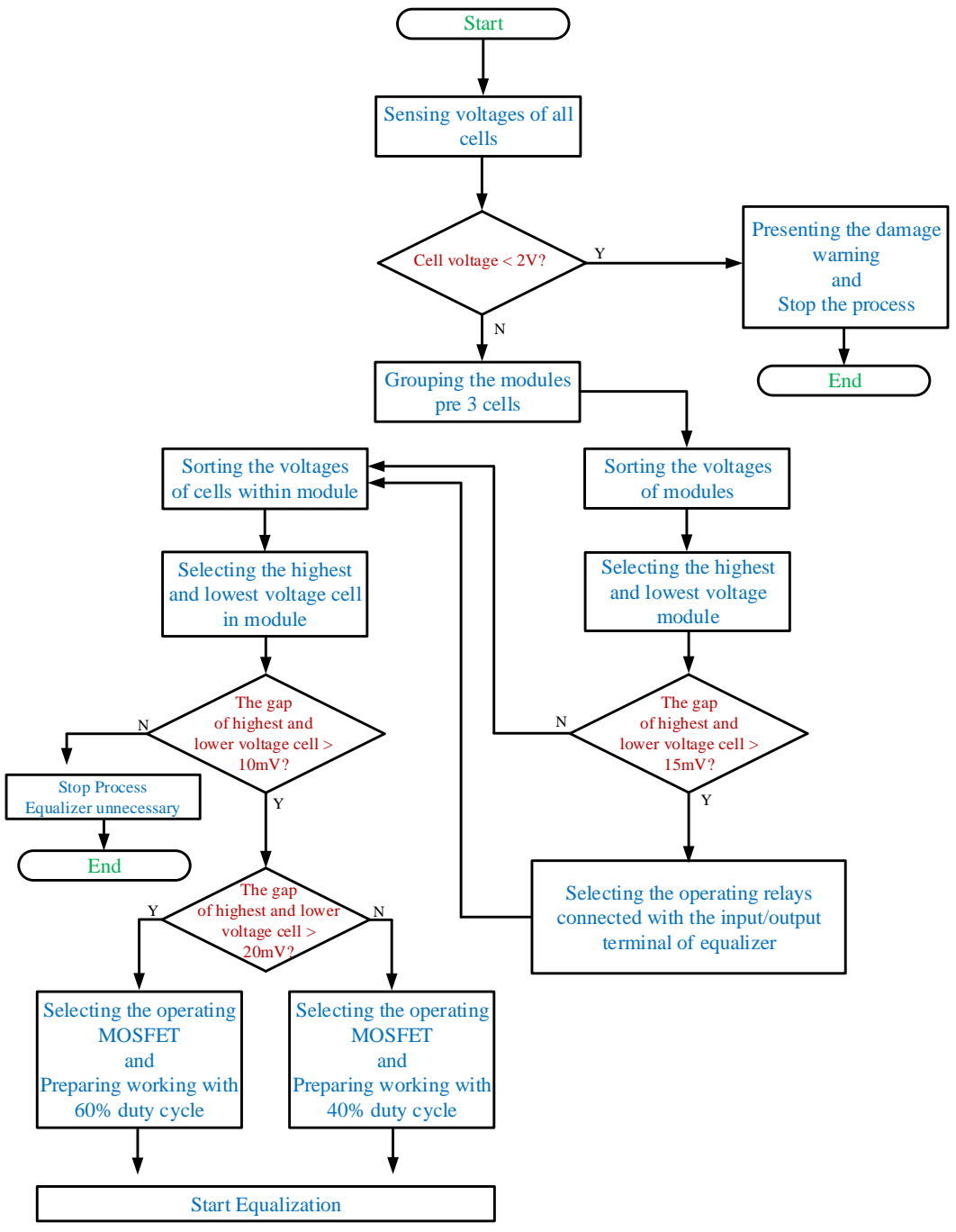

Figure 12. The flow chart of the control program for EWM. 


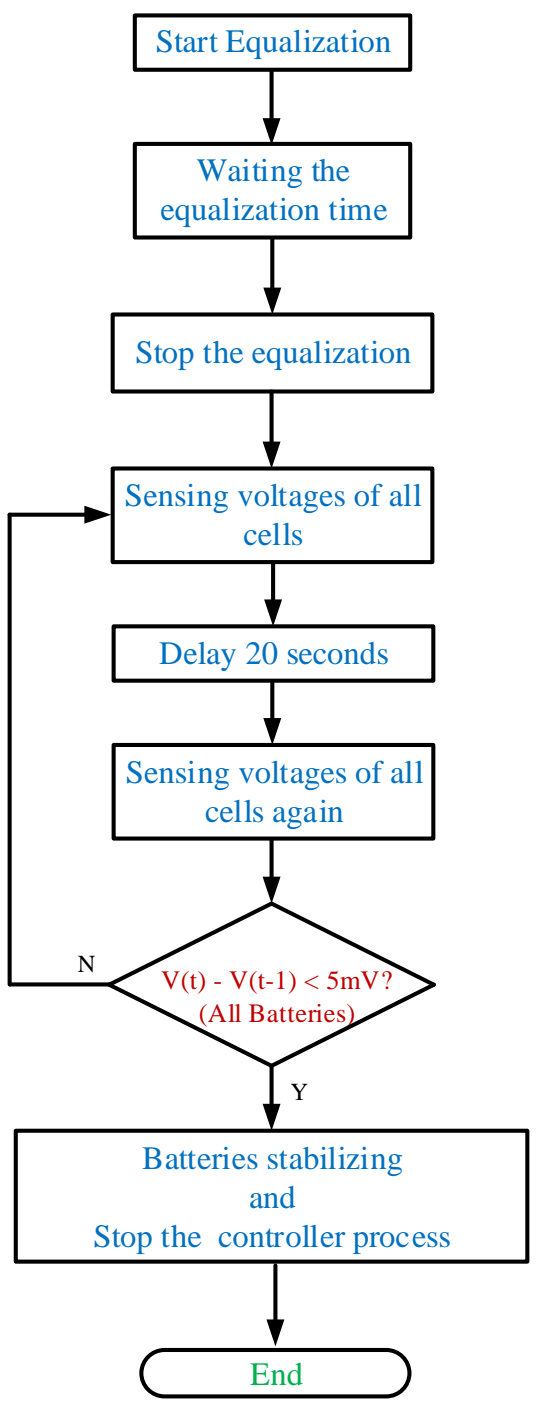

Figure 13. The flow chart of the control program for EBM.

\section{Experimental Results of Proposed Equalization System}

For power batteries in electric vehicles, $\mathrm{LiFePO}_{4}$ batteries are considered to be the fastest growing in the lithium-ion battery family, because $\mathrm{LiFePO}_{4}$ batteries have many advantages. In terms of safety, $\mathrm{LiFePO}_{4}$ batteries do not have safety hazards such as overheating and explosion. In terms of cost, the cathode material of $\mathrm{LiFePO}_{4}$ batteries is cheaper than $\mathrm{LiNiO}_{2}$ batteries and $\mathrm{LiCoO}_{2}$ batteries. In addition, the cycle life of $\mathrm{LiFePO}_{4}$ batteries is four to five times that of lithium batteries, and the weight is reduced by 30 to $50 \%$. Therefore, the $\mathrm{LiFePO}_{4}$ battery, which is PC40100LEP_10Ah, is employed in the experiments of the proposed battery equalization system. In addition, the nominal capacity and voltage of the utilized $\mathrm{LiFePO}_{4}$ battery are $10 \mathrm{Ah}$ and $3.3 \mathrm{~V}$, respectively.

\subsection{The Experimental Results of Equalizer within Module}

The parameters and components utilized in the prototype circuit of the proposed equalizer within module are presented in Table 1. The circuit photo of the proposed equalizer within module used for experiment is shown in Figure 14, and the experimental waveforms of the proposed equalizer within module are shown in Figure 15. 
Table 1. The parameters and components utilized in the prototype circuit of the proposed equalizer within module.

\begin{tabular}{cc}
\hline Parameter/Component & Value \\
\hline Input Voltage $V_{i}$ & $2.1 \mathrm{~V} \sim 3.65 \mathrm{~V}$ \\
Output Voltage $V_{o}$ & $2.1 \mathrm{~V} \sim 3.65 \mathrm{~V}$ \\
Switching Frequency & $50 \mathrm{kHz}$ \\
Maximum Power $P_{\mathrm{o}}$ & $15 \mathrm{~W}$ \\
Inductors $L_{1}, L_{2}, L_{3}$ & $6 \mu \mathrm{H}$ \\
Power Switches $S W_{1}, S W_{2}, S W_{3}$ & IRFB4510 \\
Rectifier Didoes $D_{1}, D_{2}, D_{3}$ & MBR10100 \\
Photocoupler & TLP250
\end{tabular}

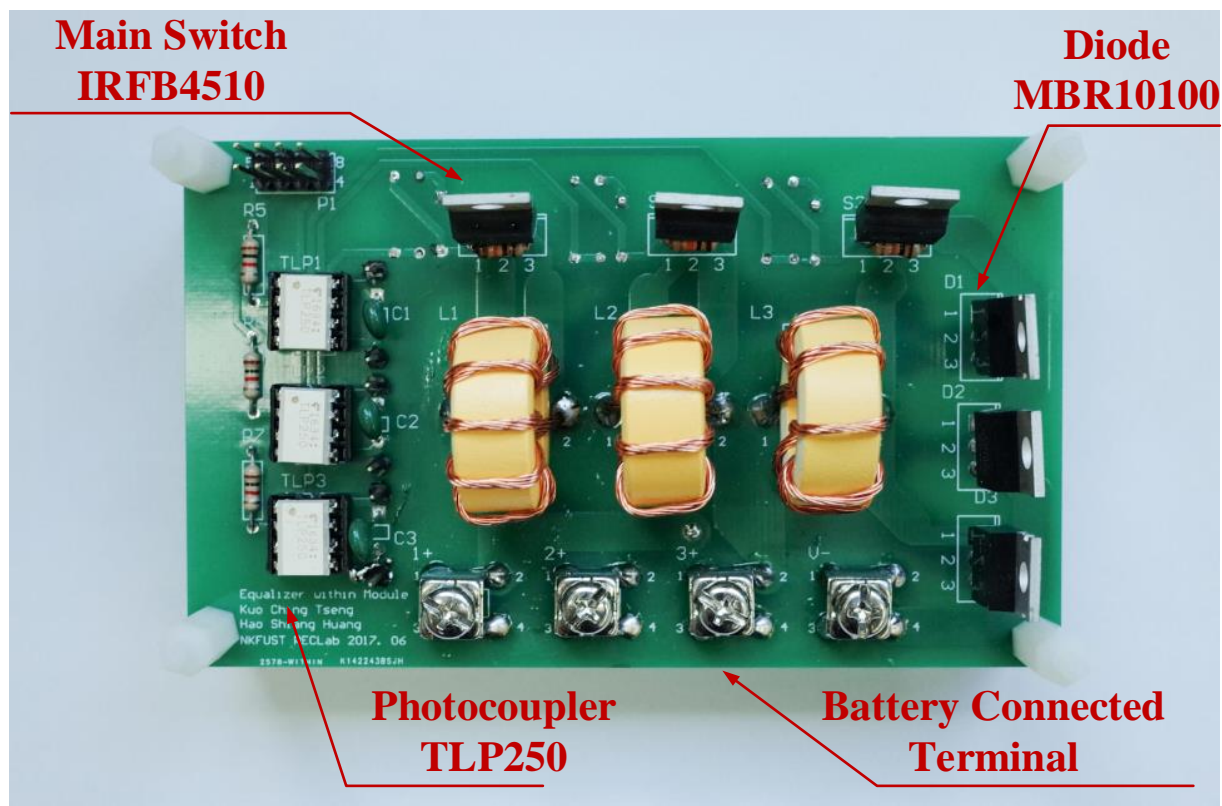

Figure 14. The circuit photo of the proposed equalizer within module.

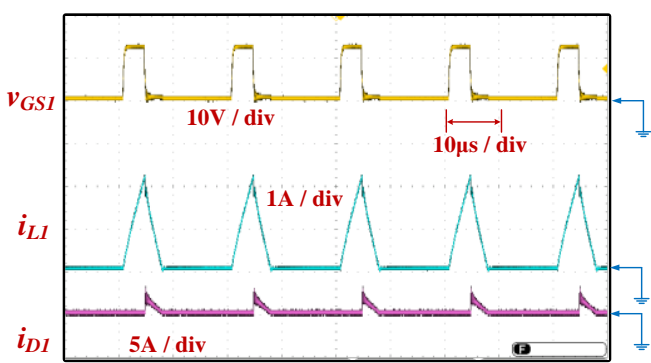

(a)

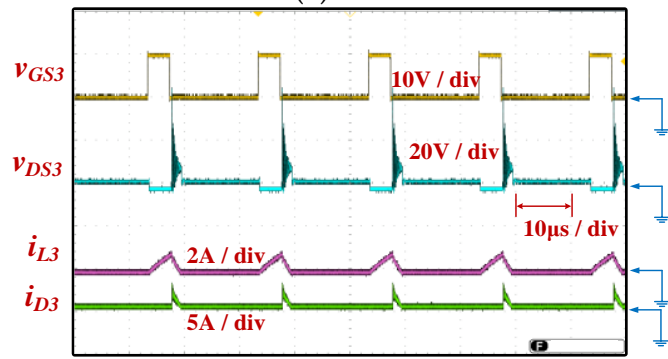

(c)

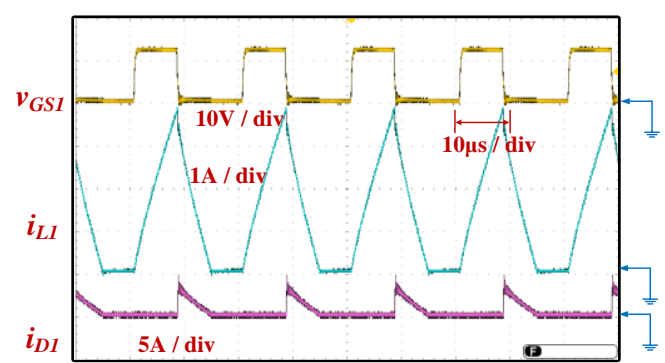

(b)

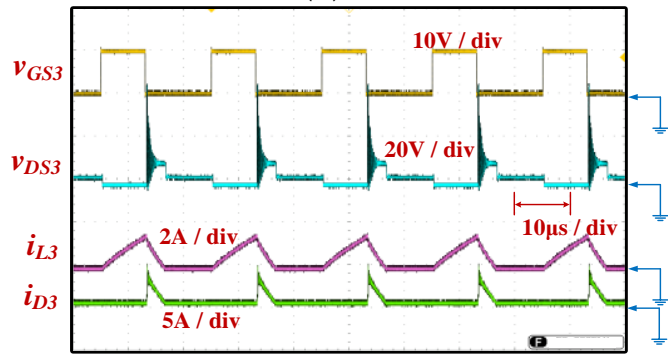

(d)

Figure 15. The experimental waveforms of the proposed equalizer within module: Measured $v_{G S 1}, i_{L 1}$, and $i_{D 1}$ at (a) $20 \%$ and (b) $40 \%$ duty cycle of $S W_{1}$; Measured $v_{G S 3}, v_{D S 3}, i_{L 3}$, and $i_{D 3}$ at (c) $20 \%$ and (d) $40 \%$ duty cycle of $S W_{3}$. 
Figure $15 \mathrm{a}, \mathrm{b}$ respectively show the gate-driving signal $v_{G S 1}$ with $20 \%$ and $40 \%$ duty cycle of the power switch $S W_{1}$, the current $i_{L 1}$ of the inductor $L_{1}$, and the current $i_{D 1}$ of the diode $D_{1}$.

Figure $15 \mathrm{c}$,d respectively show the gate-driving signal $v_{G S 3}$ with duty cycles $20 \%$ and $40 \%$, the voltage $v_{D S 3}$ of the power switch $S W_{3}$, the current $i_{L 3}$ of inductor $L_{3}$, and the current $i_{D 3}$ of diode $D_{3}$. In addition, the controller used in the proposed system can adjust the balancing speed of the battery cells by changing the duty cycle of the power switch.

\subsection{The Experimental Results of Equalizer between Modules}

The parameters and components utilized in the prototype circuit of the proposed equalizer between modules are shown in Table 2 .

Table 2. The parameters and components utilized in the prototype circuit of the proposed equalizer between modules.

\begin{tabular}{cc}
\hline Parameter/Component & Value \\
\hline Input Voltage $V_{i}$ & $9.9 \mathrm{~V}$ \\
Output Voltage $V_{o}$ & $10.95 \mathrm{~V} \sim 12 \mathrm{~V}$ \\
Switching Frequency & $50 \mathrm{kHz}$ \\
Maximum Power $P_{\mathrm{o}}$ & $40 \mathrm{~W}$ \\
Duty Ratio & 0.55 \\
Turns Ratio $\left(N_{P}: N_{S}\right)$ & $1: 1$ \\
Magnetizing Inductor $L_{m}$ & $8.6 \mu \mathrm{H}$ \\
Snubber Inductor $L_{\text {snu }}$ & $4.3 \mu \mathrm{H}$ \\
Snubber Capacitor $C_{\text {snu }}$ & $150 \mathrm{nF}$ \\
Input Capacitor $C_{\text {in }}$ & $470 \mu \mathrm{F}$ \\
Output Capacitor $C_{\text {out } 2}$ & $2700 \mu \mathrm{F}$ \\
Power Switches $S W_{1}$ & IRFP4310 \\
Snubber Diodes $D_{1}, D_{2}$ & FCQ30A03L \\
Rectifier Diode $D_{3}$ & FCQ03A04 \\
PWM IC & UC3843 \\
Photocoupler & TLP250 \\
\hline
\end{tabular}

The circuit photo of the proposed equalizer between modules used for experiment is shown in Figure 16. The experimental waveforms of proposed equalizer at the full load are shown in Figure 17.

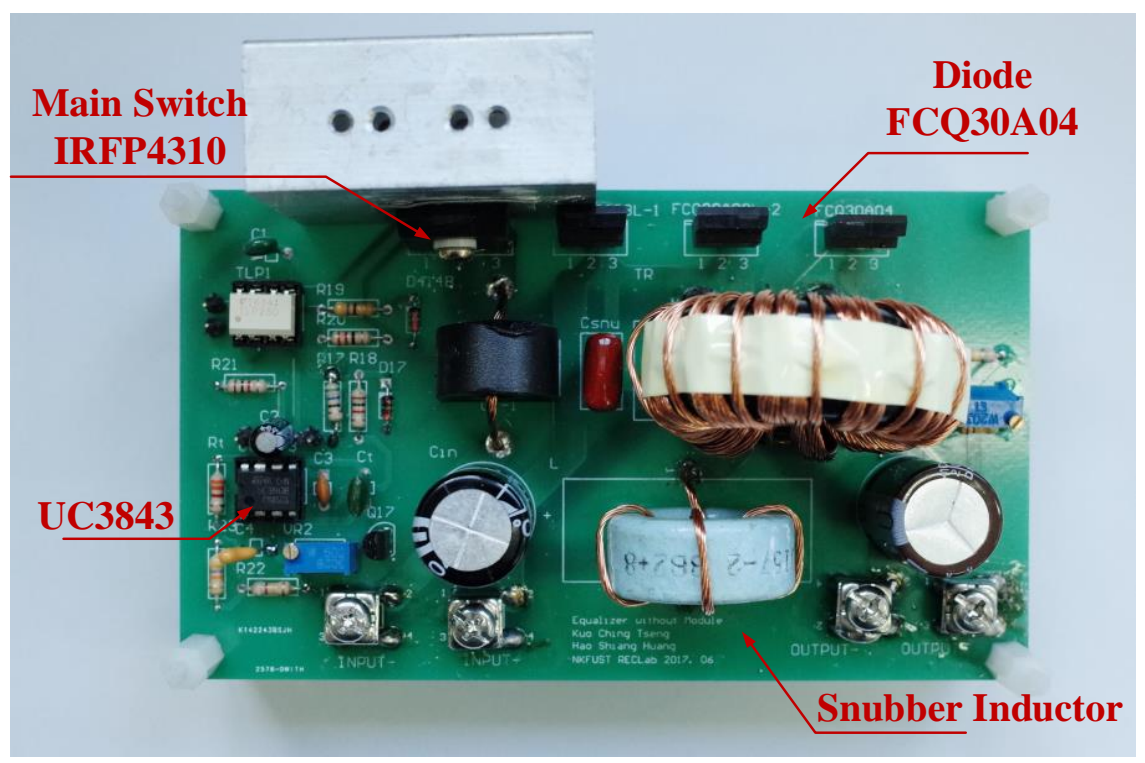

Figure 16. The circuit photo of the proposed equalizer between modules. 


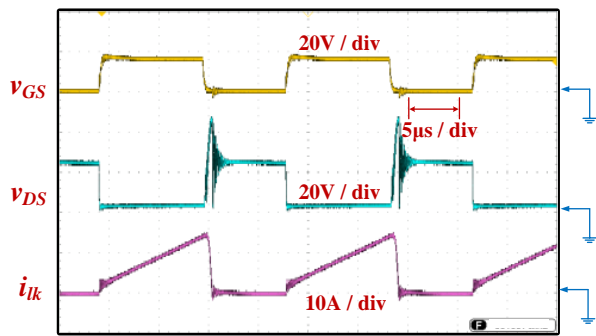

(a)

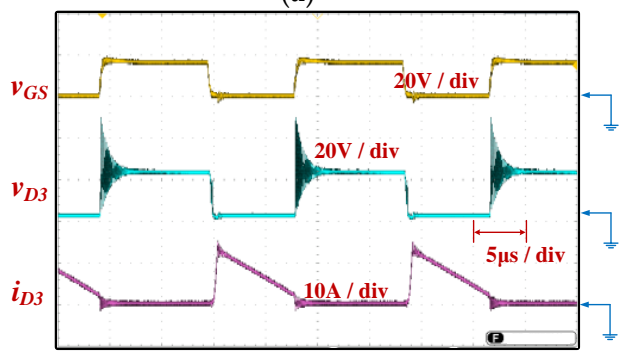

(c)

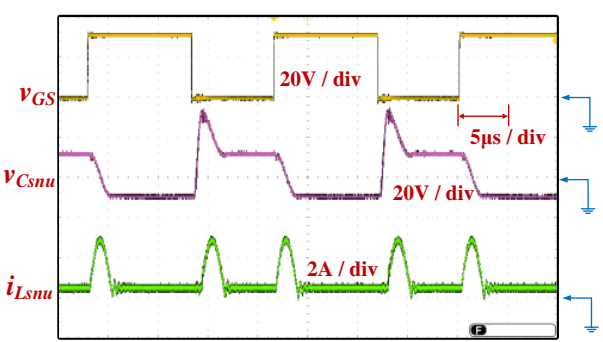

(b)

Figure 17. The experimental waveforms of the proposed equalizer between modules: (a) Measured $v_{G S}, v_{D S}$, and $i_{l k}(\mathbf{b})$ Measured $v_{G S}, v_{c s n u}$, and $i_{L s n u}(\mathbf{c})$ Measured $v_{G S}, v_{D 3}$, and $i_{D 3}$.

Figure 17a exhibits the gate-driving signal $v_{G S}$ and voltage $v_{D S}$ of the main switch SW, and the leakage inductor current $i_{l k}$. Figure $17 \mathrm{~b}$ shows the gate-driving signal of switch $\mathrm{SW}$, the voltage $v_{C S n u}$ of the snubber capacitor $C_{S n u}$, and the current $i_{L s n u}$ of the snubber inductor $L_{s n u}$. Although there is a spike voltage caused by leakage inductor and parasitic capacitance $C_{d s}$ of $S W$, the energy can be recovered to input and output via the snubber circuit. The experimental waveforms of diode $D_{3}$ are depicted in Figure $17 \mathrm{c}$, which include diode voltage $v_{D 3}$ and current $i_{D 3}$ along with the gate-driving signal $v_{G S}$.

\subsection{The Experimental Results of the Proposed Battery Equalization System}

Twelve $\mathrm{LiFePO}_{4}$ batteries with uneven battery voltage are applied to the proposed battery equalization system with hierarchical equalization charging topology to demonstrate the function, and the circuit photo of the overall proposed battery equalization system is shown in Figure 18.

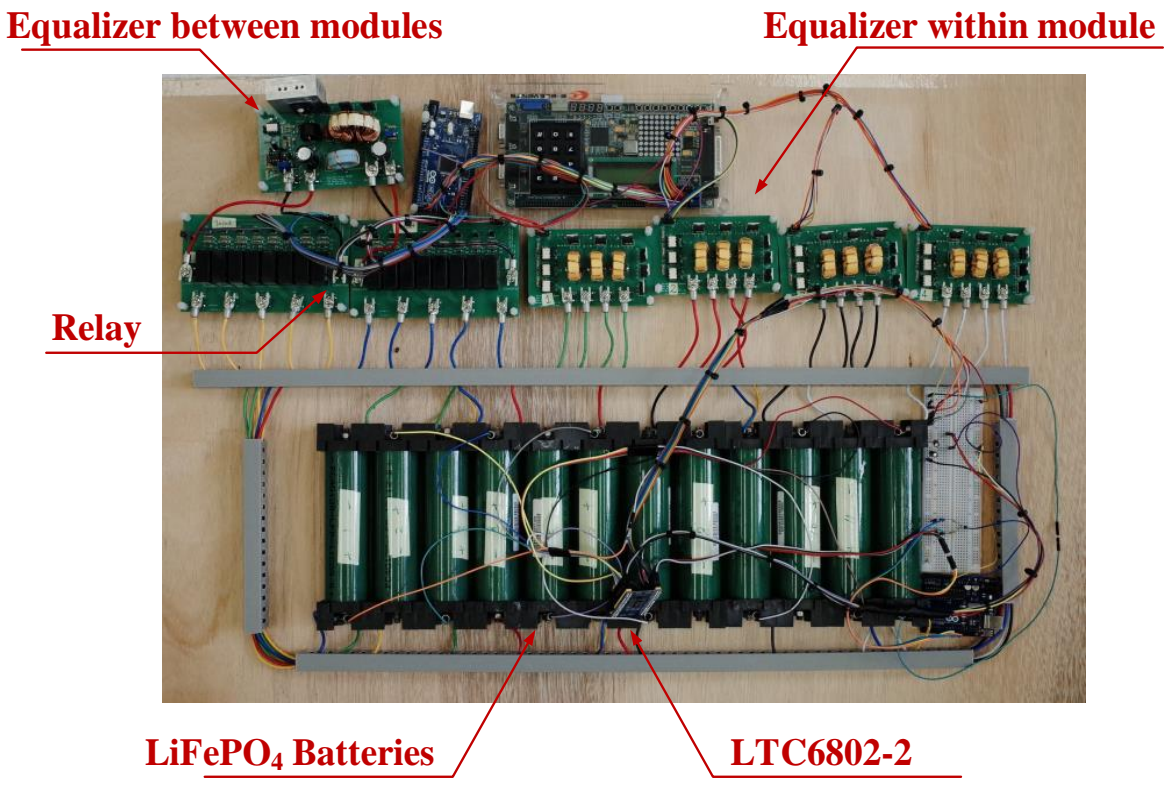

Figure 18. The circuit photo of the overall proposed battery equalization system. 
The experimental results of the proposed battery equalization system are presented in two parts: static equalization and dynamic equalization. The experimental battery pack consisted of four modules. The detailed static equalization process and measured voltage of each battery cell in Module A, Module B, Module C, and Module D are shown in Figure 19a-d, respectively. In addition, the voltages of each cells in the Modules are measured per $30 \mathrm{~s}$, and the total battery balancing time is $5 \mathrm{~min}$. The battery voltage varies greatly from $0 \mathrm{~s}$ to $30 \mathrm{~s}$ and $300 \mathrm{~s}$ to final, because the ohmic polarization voltage of the battery responds quickly with the change of the battery charging and discharging state; the concentration polarization voltage response is slow and irregular. Therefore, during the charge/discharge phase, there is a significant difference in the polarization voltage of the battery. On the other hand, the overall experimental result of static equalization in the proposed battery equalization system is presented in Figure 20. As shown in Figure 20, the initial voltage of each cell before battery equalization is indicated by the blue line. In addition, the final voltage of each cell after battery equalization is indicated by a green line. Obviously, the difference in battery voltage is gradually eliminated by the proposed battery equalization scheme. Since the initial battery pack voltage of Module A is the lowest, and the initial battery pack voltage of Module D is the highest, the proposed battery equalization system performs the operation of equalizer between modules. Therefore, the battery pack voltage of Module A increases significantly, as shown in Figure 19a. Moreover, the equalizer within modules is effective, which can prevent the over-discharge of the No. 11 battery cell in Module D, as shown in Figure 19d. In addition, the maximum voltage difference of the total battery cells before and after balancing is reduced from 70 to $36 \mathrm{mV}$, as shown in Figure 18.

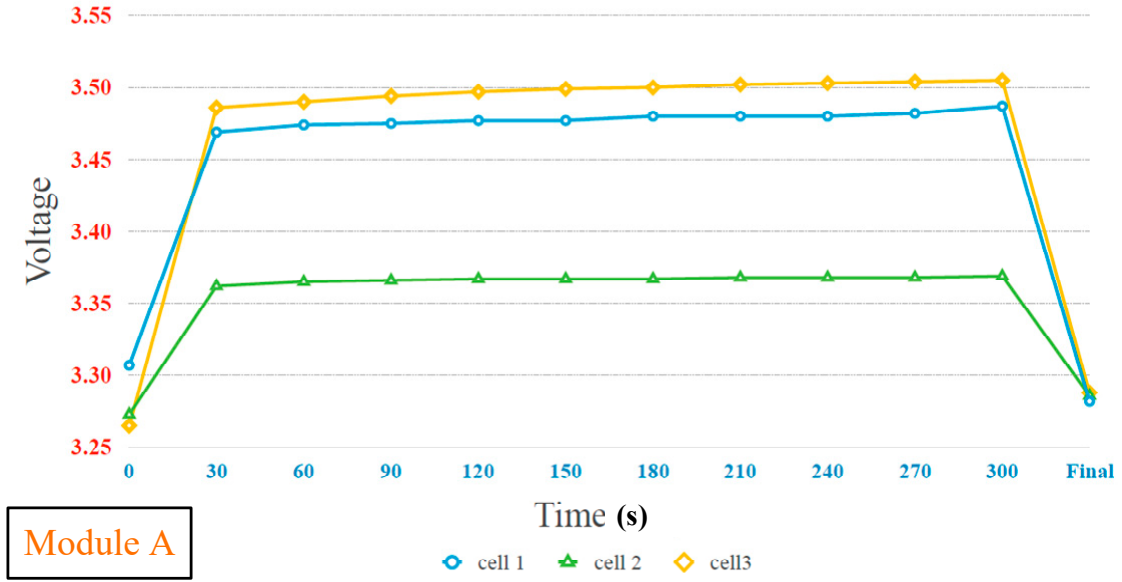

(a)

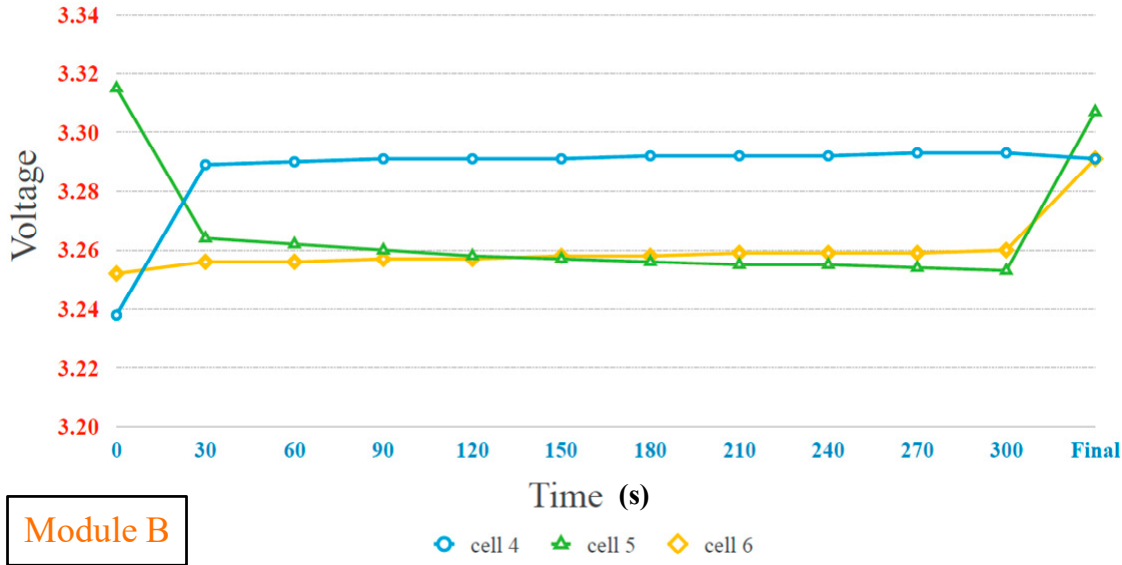

(b)

Figure 19. Cont. 


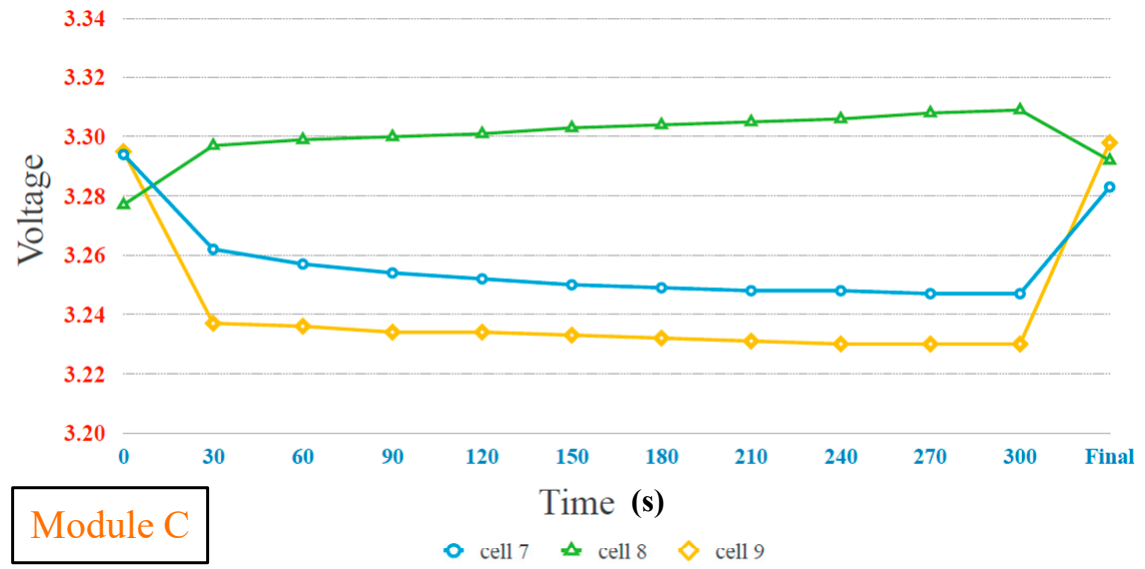

(c)

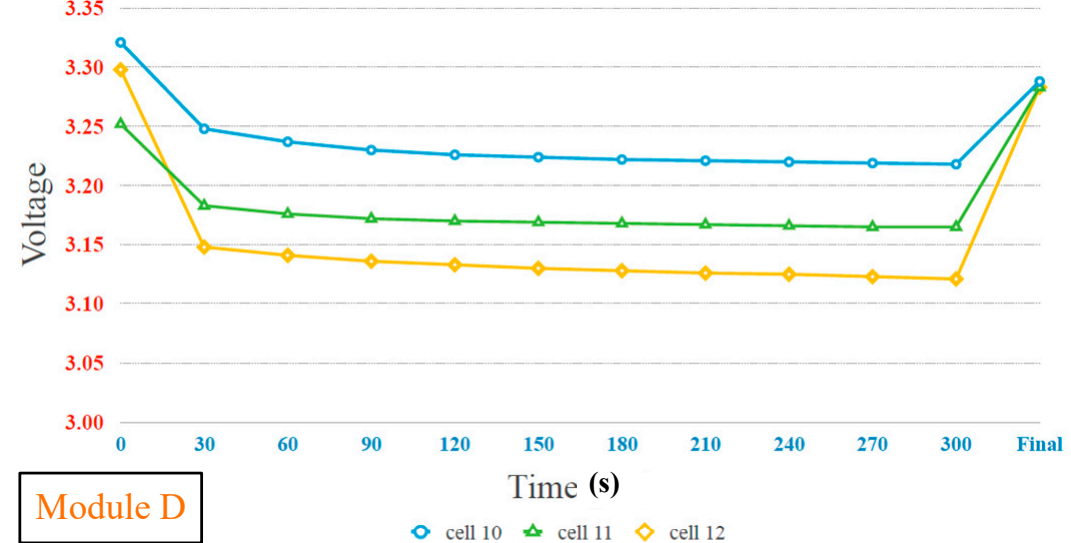

(d)

Figure 19. The experiment results of measured voltages in each modules at static equalization process: (a) Module A (b) Module B (c) Module C (d) Module D.

On the other hand, the balance of the battery in the process of charging and discharging, that is, dynamic equalization, is both complicated and necessary. The dynamic balance experiment of the battery pack includes the charging and discharging process, and the charging and discharging currents are both $0.2 \mathrm{C}$. The total operating time of the dynamic balance experiment is $5 \mathrm{~min}$.

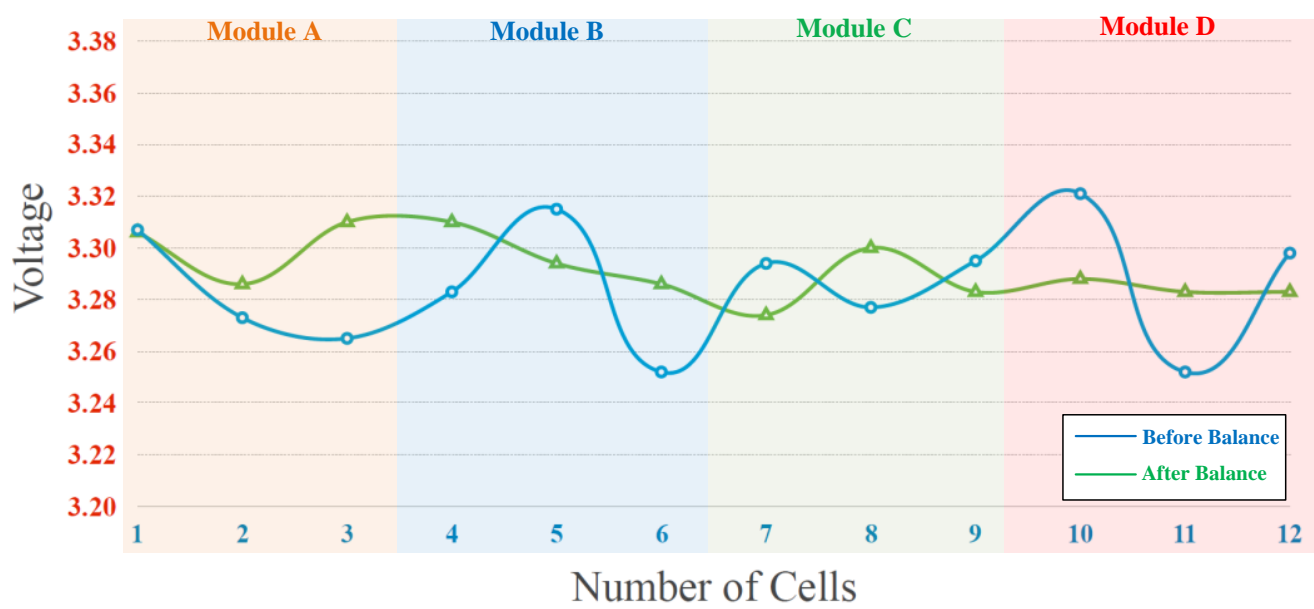

Figure 20. The overall experiment result of static equalization in the proposed battery equalization system. 
The experimental result of dynamic equalization of the battery pack in the charging process is shown in Figure 21. During the charging process of the battery pack, the voltage difference between Module C and Module D is greatly improved. Since the voltage of the No. 6 battery cell is significantly lower than other batteries, the charging intensity is increased by the proposed equalizer. In addition, the maximum voltage difference of the total battery cells before and after balancing is reduced from 60 to $40 \mathrm{mV}$, as shown in Figure 21.

Besides, the experiment result of dynamic equalization of the battery pack in the discharging process is presented in Figure 22. Since the battery cell voltage of module A is the lowest among the four modules, the proposed equalizer activates dynamic equalization to achieve battery voltage balance. In addition, the maximum voltage difference of the total battery cells before and after balancing is reduced from 47 to $35 \mathrm{mV}$, as shown in Figure 22 .

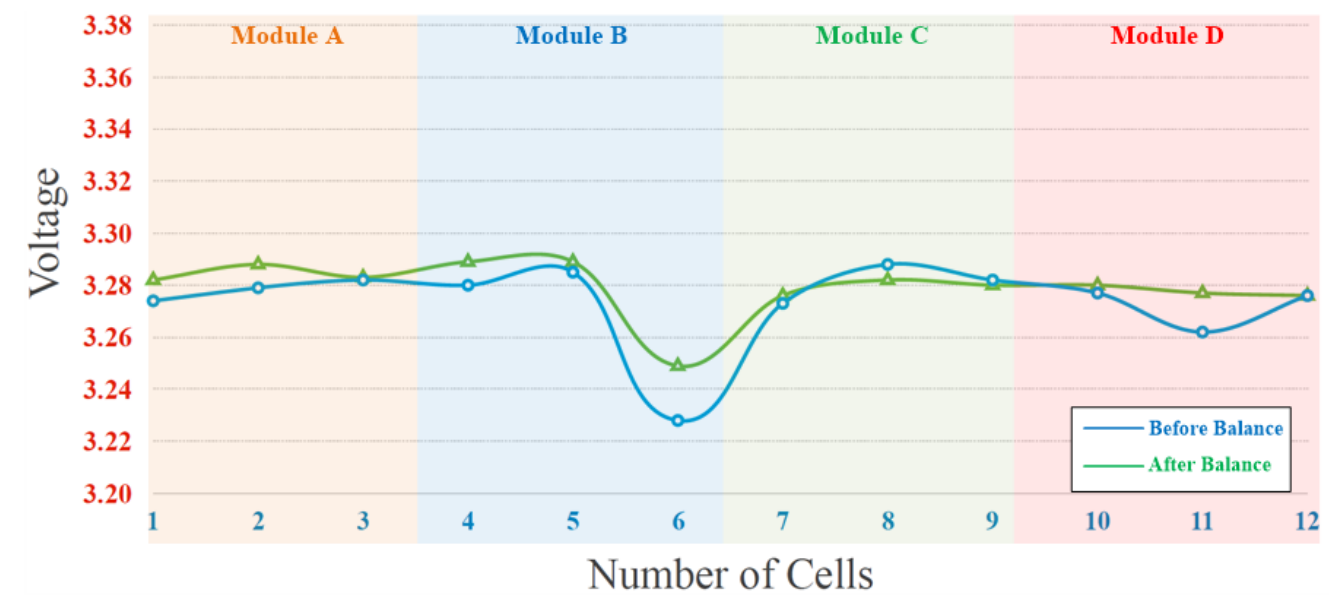

Figure 21. The experiment result of dynamic equalization during charging.

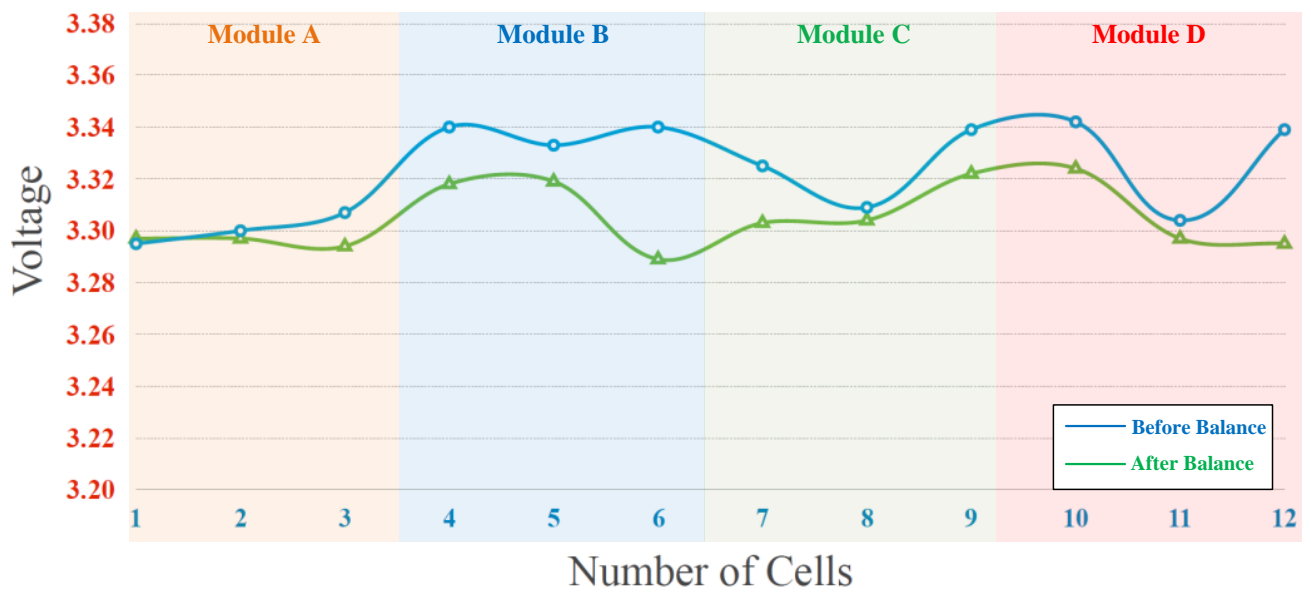

Figure 22. The experiment result of dynamic equalization during discharging.

\section{Discussion}

From experimental results shown in Figure 19a-d, it can be calculated that the average voltage of twelve cells within four modules is $3.2823 \mathrm{~V}$ before battery equalization. The maximum and minimum deviations with respect to the average voltage before battery equalization are 38.7 and $30.3 \mathrm{mV}$, respectively. Besides, it can be calculated that the average voltage of twelve cells within four modules is $3.2893 \mathrm{~V}$ after battery equalization. The maximum and minimum deviations with respect to the average voltage after battery equalization are 17.7 and $7.3 \mathrm{mV}$, respectively. In addition, the maximum deviations with respect to the average voltage before and after battery equalization are $1.18 \%$ and $0.538 \%$, 
respectively. Therefore, in the proposed battery equalization system, an improvement of about $50 \%$ can be achieved in reducing the deviation of the battery voltage.

Table 3 shows comparisons of performance between the existing balance methods and the proposed HECT one. The switched capacitor method has high balance efficiency, and the multi-winding transformer method has a fast balance speed. Besides, the methods of bleed resister, analog shunting, and switched capacitor have excellent balance control. In addition, the advantages of the proposed HECT scheme are good balance efficiency, good balance speed, moderate balance control, and it is suitable for modular design.

Table 3. Comparisons of Performance.

\begin{tabular}{ccccc}
\hline Balance Method & Balance Efficiency & Balance Speed & Balance Control & Modular Design \\
\hline Bleed Resister & Poor & Good & Excellent & Yes \\
Analog Shunting & Poor & Good & Excellent & Yes \\
Switched Capacitor & Excellent & Good & Excellent & Yes \\
Multi-Winding Transformer & Moderate & Excellent & Good & No \\
Switching Transformer & Good & Moderate & Good & No \\
Proposed HECT & Good & Good & Moderate & Yes \\
\hline
\end{tabular}

\section{Conclusions}

This paper proposes a power conversion technique with a hierarchical equalization charging topology, which is suitable for series-connected battery systems. The scheme combines an equalizer within a module and an equalizer between modules. The proposed battery equalizer improves the unbalanced condition of the battery voltage, thereby ensuring the safety of the battery and prolonging the service life of the battery. The proposed equalizer reduces the steps required for battery balancing through modular batteries and a hierarchical architecture, so as to accelerate the speed of battery balancing. During the experiment, $12 \mathrm{LiFePO}_{4}$ batteries were used. The experimental results show that the battery voltage deviation is reduced by about $50 \%$, which proves the function and performance of the proposed battery equalizer with a hierarchical equalizing charging topology.

Author Contributions: K.-C.T. conceived and designed the circuit. H.-S.H. carried out the prototype circuit, measured experimental results, and wrote original draft preparation with the guidance from K.-C.T. and C.-A.C. revised and edited the manuscript for submission. All authors have read and agreed to the published version of the manuscript.

Funding: The APC was funded by the Ministry of Science and Technology (MOST) of Taiwan, under its grant with reference number MOST 110-2221-E-214-014.

Conflicts of Interest: The authors declare no conflict of interest.

\section{Abbreviation Table with Units}

$\begin{array}{ll}\text { Parameter } & \text { Unit } \\ \text { Battery voltage } V_{B n} & \text { Volt } \\ \text { Switching frequency } f & \text { Hertz } \\ \text { Output power } P_{o} & \text { Watt } \\ \text { Snubber capacitor } C_{s n u} & \text { Farad } \\ \text { Snubber inductor } L_{S n u} & \text { Henry } \\ \text { Leakage inductor current } i_{\text {Llk }} & \text { Ampere } \\ \text { Input voltage } V_{i} & \text { Volt } \\ \text { Output voltage } V_{o} & \text { Volt } \\ \text { Magnetizing Inductor } L_{m} & \text { Henry } \\ \text { Input Capacitor } C_{i n} & \text { Farad } \\ \text { Output Capacitor } C_{\text {out2 }} & \text { Farad }\end{array}$




\section{References}

1. Bosshard, R.; Kolar, J.W. Inductive Power Transfer for Electric Vehicle Charging: Technical Challenges and Tradeoffs. IEEE Power Electron. Mag. 2016, 3, 22-30. [CrossRef]

2. Photovoltaics, D.G.; Storage, E. IEEE Recommended Practice for Sizing Lead-Acid Batteries for Stand-Alone Photovoltaic (PV) Systems. In IEEE Std 1013-2007 (Revision of IEEE Std 1013-2000); IEEE: Piscataway, NJ, USA, 2007; pp. 1-55. [CrossRef]

3. Greenleaf, M.; Dalchand, O.; Hui, L.; Zheng, J.P. A Temperature Dependent Study of Sealed Lead-Acid Batteries Using Physical Equivalent Circuit Modeling with Impedance Spectra Derived High Current/Power Correction. IEEE Trans. Sustain. Energy 2015, 6, 380-387. [CrossRef]

4. Cai, Z.H.; Liu, G.F.; Luo, J. Research State of Charge Estimation Tactics of Nickel-Hydrogen Battery. In Proceedings of the International Symposium on Intelligence Information Processing and Trusted Computing (IPTC'10), Huanggang, China, 28-29 October 2010; pp. 184-187.

5. Hu, X.; Li, S.E.; Yang, Y. Advanced Machine Learning Approach for Lithium-Ion Battery State Estimation in Electric Vehicles. IEEE Trans. Transp. Electrif. 2016, 2, 140-149. [CrossRef]

6. Hoke, A.; Brissette, A.; Smith, K.; Pratt, A.; Maksimovic, D. Accounting for Lithium-Ion Battery Degradation in Electric Vehicle Charging Optimization. IEEE J. Emerg. Sel. Topics Power Electron. 2014, 2, 691-700. [CrossRef]

7. Tesla Model S. Available online: https:/ / en.wikipedia.org/wiki/Tesla_Model_S\#Battery (accessed on 25 August 2021).

8. Huang, S.T.; Hopkins, D.C.; Mosling, C.R. Extension of Battery Life via Charge Equalization Control. IEEE Trans. Ind. Electron. 1993, 40, 96-104. [CrossRef]

9. Kimball, J.W.; Kuhn, B.T.; Krein, P.T. Increased Performance of Battery Packs by Active Equalization. In Proceedings of the 2007 IEEE Vehicle Power and Propulsion Conference, Arlington, TX, USA, 9-12 September 2007; pp. 323-327.

10. Yarlagadda, S.; Hartley, T.T.; Husain, I. A Battery Management System Using An Active Charge Equalization Technique Based on A DC/DC Converter Topology. IEEE Trans. Ind. Appl. 2013, 49, 2721-2730. [CrossRef]

11. Elsayed, A.T.; Lashway, C.R.; Mohammed, O.A. Advanced Battery Management and Diagnostic System for Smart Grid Infrastructure. IEEE Trans. Smart Grid 2016, 7, 897-905.

12. Jian, Q.; Lu, D.D.C. Review of Battery Cell Balancing Techniques. In Proceedings of the 2014 Australasian Universities Power Engineering Conference (AUPEC), Perth, Australia, 28 September-1 October 2014; pp. 1-6.

13. Raman, S.R.; Xue, X.D.; Cheng, K.W.E. Review of Charge Equalization Schemes for Li-Ion Battery and Super-Capacitor Energy Storage Systems. In Proceedings of the 2014 International Conference on Advances in Electronics Computers and Communications, Bangalore, India, 10-11 October 2014; pp. 1-6.

14. Hui, X.; Yatao, F.; Yiying, W. Review of Equalizing Methods for Battery Pack. In Proceedings of the 2014 17th International Conference on Electrical Machines and Systems (ICEMS), Hangzhou, China, 22-25 October 2014; pp. 871-877.

15. Stuart, T.; Zhu, W. Fast Equalization for Large Lithium Ion Batteries. IEEE Trans. Aerosp. Electron. Syst. 2009, 24, 27-31. [CrossRef]

16. Zheng, Y.; Ouyang, M.; Lu, L.; Li, J.; Han, X.; Xu, L. On-Line Equalization for Lithium-Ion Battery Packs Based on Charging Cell Voltages: Part 2. Fuzzy logic equalization. J. Power Sources 2014, 247, 460-466. [CrossRef]

17. Teofilo, V.L.; Merritt, L.V.; Hollandsworth, R.P. Advanced Lithium Ion Battery Charger. IEEE Trans. Aerosp. Electron. Syst. 1997, 12, 30-36. [CrossRef]

18. Daowd, M.; Omar, N.; Bossche, P.V.; Mierlo, J.V. Passive and Active Balancing Comparison Based on MATLAB Simulation. In Proceedings of the 2011 IEEE Vehicle Power and Propulsion Conference, Chicago, IL, USA, 6-9 September 2011; pp. 1-7.

19. Uno, M.; Tanaka, K. Double-Switch Single-Transformer Cell Voltage Equalizer Using a Half-Bridge Inverter and a Voltage Multiplier for Seriesconnected Supercapacitors. IEEE Trans. Veh. Technol. 2012, 61, 3920-3930. [CrossRef]

20. Uno, M.; Tanaka, K. Single-Switch Multioutput Charger Using Voltage Multiplier for Series-Connected Lithium-Ion Battery/Supercapacitor Equalization. IEEE Trans. Ind. Electron. 2013, 60, 3227-3239. [CrossRef]

21. Ye, Y.; Cheng, K.W.E. Modeling and Analysis of Series-Parallel Switched-Capacitor Voltage Equalizer for Battery/Supercapacitor Strings. IEEE J. Emerg. Sel. Top. Power Electron. 2015, 3, 977-983. [CrossRef]

22. Park, H.S.; Kim, C.E.; Kim, C.H.; Moon, G.W.; Lee, J.H. A Modularized Charge Equalizer for an HEV Lithium-Ion Battery String. IEEE Trans. Ind. Electron. 2009, 56, 1464-1476. [CrossRef]

23. Baughman, A.C.; Ferdowsi, M. Double-Tiered Switched-Capacitor Battery Charge Equalization Technique. IEEE Trans. Ind. Electron. 2008, 55, 2277-2285. [CrossRef]

24. Kim, M.Y.; Kim, C.H.; Kim, J.H.; Moon, G.W. A Chain Structure of Switched Capacitor for Improved Cell Balancing Speed of Lithium-Ion Batteries. IEEE Trans. Ind. Electron. 2014, 61, 3989-3999. [CrossRef]

25. Chen, W.L.; Cheng, S.R. Optimal Charge Equalisation Control for Series-Connected Batteries. IET Gener. Transmiss. Distrib. 2013, 7, 843-854. [CrossRef]

26. Lee, Y.S.; Cheng, G.T. Quasi-Resonant Zero Current Switching Bidirectional Converter for Battery Equalization Applications. IEEE Trans. Power Electron. 2006, 21, 1213-1224. [CrossRef]

27. Kim, M.Y.; Kim, J.H.; Moon, G.W. Center-Cell Concentration Structure of a Cell-to-Cell Balancing Circuit with a Reduced Number of Switches. IEEE Trans. Power Electron. 2014, 29, 5285-5297. [CrossRef]

28. Yuanmao, Y.; Cheng, K.W.E.; Yeung, Y.P.B. Zero-Current Switching Switched-Capacitor Zero-Voltage-Gap Automatic Equalization System for Series Battery String. IEEE Trans. Power Electron. 2012, 27, 3234-3242. [CrossRef] 
29. Park, S.H.; Ki, T.S.; Park, J.S.; Moon, G.W.; Yoon, M.J. A New Buck-Boost Type Battery Equalizer. In Proceedings of the 2009 Twenty-Fourth Annual IEEE Applied Power Electronics Conference and Exposition, Washington, DC, USA, 15-19 February 2009; pp. 1246-1250.

30. Shang, Y.; Zhang, C.; Cui, N.; Guerrero, J.M. A Cell-to-Cell Battery Equalizer with Zero-Current Switching and Zero-Voltage Gap Based on Quasiresonant LC Converter and Boost Converter. IEEE Trans. Power Electron. 2015, 30, 3731-3747. [CrossRef]

31. Zhang, Z.; Gui, H.; Gu, D.J.; Yang, Y.; Ren, X. A Hierarchical Active Balancing Architecture for Lithium-Ion Battery. IEEE Trans. Power Electron. 2017, 32, 2757-2768. [CrossRef]

32. Robert, W. Erickson and Dragan Maksimovic, Fundamentals of Power Electronics, 2nd ed.; Kluwer Academic Publishers: Norwell, MA, USA, 2001.

33. Lee, J.H.; Liang, T.J.; Chen, J.F. Isolated Coupled-Inductor Integrated DC-DC Converter with Nondissipative Snubber for Solar Energy Applications. IEEE Trans. Ind. Electron. 2014, 61, 3337-3348. [CrossRef] 